\title{
Non-parental infanticide in a dense population of the Black-billed Magpie (Pica pica)
}

\author{
Sang-im Lee $\cdot$ Kyungseon Seo $\cdot$ Wonyoung Lee $\cdot$ \\ Woohjung Kim $\cdot$ Jae Chun Choe $\cdot$ Piotr Jabłoński
}

Received: 9 January 2011 / Accepted: 27 March 2011/Published online: 21 June 2011

(C) The Author(s) 2011. This article is published with open access at Springerlink.com

\begin{abstract}
We report the first case of non-parental infanticide in the Black-billed Magpie Pica pica. Using a video camera installed in the victims' nest, we recorded repeated visits (over 4 days) of an adult (each time one bird) who attacked six nestlings at each visit until they died or were evicted. The nest was one of 58 nests filmed over four breeding seasons. Collected evidence suggests that the perpetrator(s) might have been the female breeder of the neighbouring nest, possibly also her male partner. The parental female aggressively attacked the perpetrator. Post-infanticide expansion of breeding territory by the suspected perpetrator is the hypothetical ultimate explanation of the observed infanticide. Movie clips from inside the nest are shown at:
\end{abstract}

Electronic supplementary material The online version of this article (doi:10.1007/s10164-011-0275-z) contains supplementary material, which is available to authorized users.

\section{S. Lee}

Institute of Advanced Machinery and Design,

Seoul National University, Seoul 151-742,

South Korea

S. Lee $(\bowtie) \cdot$ K. Seo $\cdot$ W. Lee · W. Kim · P. Jabłoński

Laboratory of Behavioural Ecology and Evolution,

Department of Biological Sciences, College of Natural Sciences,

Seoul 151-742, South Korea

e-mail: MagpieKorea@gmail.com

\section{J. C. Choe}

Laboratory of Behaviour and Ecology,

Division of EcoScience, Ewha Woman's University,

Seoul 120-750, South Korea

P. Jabłoński $(\bowtie)$

Centre for Ecological Studies, Polish Academy of Sciences,

Dziekanów Leśny 05092 Lomianki, Poland

e-mail: SNULBEE@behecolpiotrsangim.org http://www.momo-p.com/showdetail-e.php?movieid=momo 110422pp01a, http://www.momo-p.com/showdetail-e.php? movieid=momo1 10422bm01a, http://www.momo-p.com/ showdetail-e.php?movieid=momo110422pp02a, and http:// www.momo-p.com/showdetail-e.php?movieid=momo110422 pp03a.

Keywords Infanticide $\cdot$ Black-billed Magpie $\cdot$ Sexual selection - Competition - Density dependence

\section{Introduction}

In comparison to avian parental infanticide, non-parental infanticide in birds - which refers to the cases where the perpetrator is not a biological parent of the victim-is much rarer, and less well understood (Hausfater and Hrdy 1984). Three adaptive hypothetical functions have been suggested for non-parental infanticide in animals (Hrdy 1979): (1) direct exploitation of the nestlings as a resource for nutrients (i.e. cannibalism), (2) increasing access to the resource including nest site and food availability ("resource competition" hypothesis), and (3) increasing mating opportunities for the perpetrator ("sexual selection" hypothesis) by killing the offspring of other individuals. Although several decades of research have brought theoretical advances in understanding the evolution of infanticidal behaviour (Hrdy 1979; Mock 1995; Veiga 2000), empirical evidence for evaluating these hypotheses, especially in avian females, is still relatively scarce.

So far, infanticidal events have been largely reported in polygamous, colonial breeding or group-cooperatively breeding avian species, where they can lead to increased access to nesting sites and an increased probability that the affected parent(s) redirect parental care to the perpetrators' 
offspring, or they may benefit the perpetrator by making the parent of the killed offspring available for mating (Emlen et al. 1989; Fujioka 1986; Hansson et al. 1997; Inoue et al. 2010; Kaplan 2004; Kermott et al. 1991; Mumme et al. 1983; Parsons 1971; Trail et al. 1981; Veiga 1990, 2000, 2003, 2004).

Most evidence in birds concerns infanticide by males (Veiga 2000), but the number of species where avian females commit infanticide is increasing. However, statistically solid evidence of infanticide by females in a traditional mating system is based on indirect (Hansson et al. 1997; Møller 2004; Veiga 2004) rather than on direct detailed observations of the perpetrators killing the nestlings. This is because infanticide in general is rare and difficult to observe, as indicated by the fact that only 17 direct observations of infanticide have been reported in 25 years of studies of 98 broods (on average) of barn swallows per year (Møller 2004), or that only three direct observations have been noted in 10 years of studies on 60-80 broods of the house sparrow per year (Veiga 2004). Therefore, it is important to publish direct observations of infanticide, especially in species from which it has not yet been reported (examples of papers describing single infanticide events by females: Prokop et al. 2009; Shimada et al. 2002). Despite the scarcity of direct observations, some evidence suggests that the likelihood of infanticide in birds increases in high-density situations (e.g. Møller 2004). Here we present direct videotaped evidence of an aggressive infanticidal event in the dense population of the Black-billed Magpie (Pica pica sericea), a socially monogamous and solitarily breeding species, where postinfanticide expansion of breeding territory by the suspected female perpetrator is the most likely explanation.

\section{Study area}

Our study population, on the campus of Seoul National University (Seoul, Korea), has been the subject of a longterm ecological monitoring program since 1998 (Lee et al. 2010a). Its habitat is a mixture of buildings and small patches of grasslands/forests. More than 50 pairs of magpies attempt to breed annually (average density over 13 years: $49 \pm 9$ pairs $/ \mathrm{km}^{2}$; Lee et al. 2010a). Similar to European subspecies, magpies in Korea defend their territories year round, but the size of their territories is much smaller (1.1 ha; unpublished data) than they are in Europe (5 ha; Birkhead 1991; Jerzak 2001).

\section{Materials and methods}

Since 2007, we have studied nestling begging behaviour and parental feeding behaviour by installing video cameras in the nests. A total of 59 nests ( 8 in 2007, 16 in 2008, 19 in 2009 and 16 in 2010) have been recorded so far. After the nestlings had been individually marked with small dots of colour nail polish on the forehead and on the tip of the beak, we placed a bullet-shaped camera (Weatherproof Bullet Cam XB421-W36, Vision Hitech Company) with a pin-type microphone (C-Microphone, Vision Hitech Company) in the nest wall opposite to the nest entrance. In 2010 , begging and feeding were recorded digitally using a DVR located on the ground between $0700 \mathrm{~h}$ and $1100 \mathrm{~h}$ daily.

We also regularly (twice a week in a breeding season; twice a month in the following fall and winter) visited each territory to watch magpie behaviour outside the nest. These visits gave us information on the interactions of the parents from the victims' and the suspected perpetrator's nests with other neighbouring magpies.

In order to compare the year of the infanticide (2010) with previous years, we have calculated the densities (pairs $/ \mathrm{km}^{2}$ ) and breeding synchrony indices for the years 1998-2010. Breeding synchrony index was calculated as the number of temporal neighbours (the number of pairs in a $250 \mathrm{~m}$ diameter circle around the focal nest who started to lay within 3 days of the focal nest) divided by the total number of nests in a focal year (Martinez et al. 1996; Westneat 1992). In order to compare our population with typical populations of the Black-billed Magpie, we analyzed the distribution of the breeding population densities taken from a review by Jerzak (2002, Table 4). If the table showed a range of densities for a given location, we chose the centre of the range as the value contributing to the analysis.

\section{Results}

The description of the infanticidal events

On the 1st May 2010, a nestling with severe injuries on the forehead and pins on the wing and two dead siblings were found on the ground near nest 1-60. When we visited the nest area the next day, we were not able to find the parents. At that moment, it seemed as if it might have been due to premature fledging. However, in the recorded video, we could clearly see that a series of infanticidal events were carried out by a non-parental perpetrator. General information on nest 1-60 (which originally contained 6 nestlings) and neighbouring nests is given in Table 1.

Here we summarize the infanticidal events recorded in the nest 1-60 (see Table S1 of the "Electronic supplementary material" for details). On the 28th of April, the perpetrator first appeared in the nest at 07:04 a.m. The mother left the nest at 07:00 a.m. after alarm calls were 
Table 1 Information on the focal nest (1-60) and adjacent nests at the study site

\begin{tabular}{|c|c|c|c|c|c|c|}
\hline Nest & $1-60$ & $1-62$ & $2-3$ & 24 & 72 & DB \\
\hline Distance from the victim $(1-60)(\mathrm{m})$ & - & 105 & 132 & 170 & 118 & 162 \\
\hline $\begin{array}{l}\text { Presence of obstacles such as tall buildings that may } \\
\text { decrease contact between neighbours }\end{array}$ & & No & Yes & Yes & Yes & Yes \\
\hline Observed direct behavioural interactions with nest $1-60$ & & Yes & No & No & No & No \\
\hline Hatching date & $10 \mathrm{Apr}$ & $7 \mathrm{Apr}$ & - & 29 Apr & 17 Apr & Not followed \\
\hline No. of nestlings (clutch size) & 6 & $2(6)$ & $0(7)$ & $5(6)$ & $2(5)$ & \\
\hline $\begin{array}{l}\text { Age of the oldest nestling at the first incidence } \\
\text { of infanticide (days) }\end{array}$ & 20 & 23 & - & 0 & 13 & \\
\hline
\end{tabular}

heard from outside the nest. Four minutes later, the perpetrator entered the nest with alarm calls, and it continued to produce alarm calls when it pecked at a nestling who was the most accessible. The mother seemed to be outside the nest, continuously making alarm calls. The perpetrator left the nest shortly but came back to the nest at 07:28 a.m. Prior to this return of the perpetrator, the mother returned and for over 2 min the incubating mother kept producing short calls. Simultaneously, similar calls and alarm calls were heard outside the nest (http://www.momo-p.com/ showdetail-e.php?movieid=momo110422pp01a; Fig. 1a). Along with the alarm calls, sounds of pecking at the branch were heard outside, which is known as a displacement behaviour in conflict situations (Verbeek 1972), and a response to human disturbance caused by our research (pers. obs.). As soon as the perpetrator entered, the mother and the perpetrator engaged in violent physical interactions.

The perpetrator then re-entered the nest with varying intervals (from 19 to 4,824 s) over 4 days. In $72.4 \%$ of the cases (21 out of 29), the entrance of the perpetrator was accompanied by loud alarm calls heard from the outside before and after the moment of entry. The intensity and frequency of infanticidal activity was the highest on the third day (Table S1), which led to the deaths of three nestlings. Two types of infanticidal behaviour were displayed by the perpetrator: pecking attacks (http://www. momo-p.com/showdetail-e.php?movieid=momo110422b m01a; Fig. 1b) and attempts to drag the nestlings out of the nest (http://www.momo-p.com/showdetail-e.php? movieid=momo110422pp02a; Fig. 1c). The vocalizations of the nestlings during the attacks differed from normal begging (http://www.momo-p.com/showdetail-e.php? movieid=momo110422pp03a; Fig. 1d). The pecking attacks were concentrated on the forehead, pink flanges and neck of the nestling (Fig. 2).

The parents clearly reduced the number of visits during the 4 days with infanticidal activities; on 27th April (i.e. a day without any infanticidal event), the average number of visits was five times per hour, which is within the range of the average visit frequency for nests with similar brood sizes (from 4.00 to 7.50 times/h; brood sizes of 4 and 5; Lee et al. 2010b). However, during the 4 days with infanticidal events (and aggressive interactions between the parents and the perpetrator), it decreased to $3.7,0.75,0.5$, and 0.25 times/h respectively. The nestlings showed begging behaviour towards the two parents, but not towards the perpetrator (http://www.momo-p.com/showdetail-e. php?movieid=momo110422pp03a; Fig. 1d).

The identity of the perpetrator

The male breeder of the victims' nest had a mauve ring on the left leg. Although the female breeder did not have any rings, it had a worn-out tail, which allowed for identification all of the time. During the attacks when the legs were visible (16 out of 31 perpetrator's visits), the perpetrator had no rings and no noticeable physical characteristics which could have been used for identification, including a lack of worn-out tail. Thus, we are certain that the perpetrator was not the parent, at least for the visits in which legs of the perpetrator were seen in the movie.

The suspects include the breeders of neighbouring nests. The breeding male of the nearest neighbour (nest 1-62, Table 1) had red (right) and white (left) rings, so he can be excluded as the perpetrator at visits when the legs were visible. The breeding female from nest 1-62 did not have any notable features, such as a worn-out tail (characteristic of the victimized female). Breeders of other neighbouring nests were not ringed, and nor were their activities in the nests video-recorded. Nest 1-62 was not video-recorded either. However, breeders of other neighbouring nests (i.e. except 1-62) rarely interacted with the breeders of the victims' nest, which suggests that their involvement in the infanticide is less likely. It is also possible that nonbreeding floaters who sought the breeding opportunity committed infanticide in order to establish a breeding territory of their own. However, we did not observe any activities of nonbreeders near the victim's nest during the time of infanticide, and subsequently no new pair settled in this territory. Thus, although we cannot entirely exclude the possibility that the perpetrator(s) was (were) an individual (individuals) 

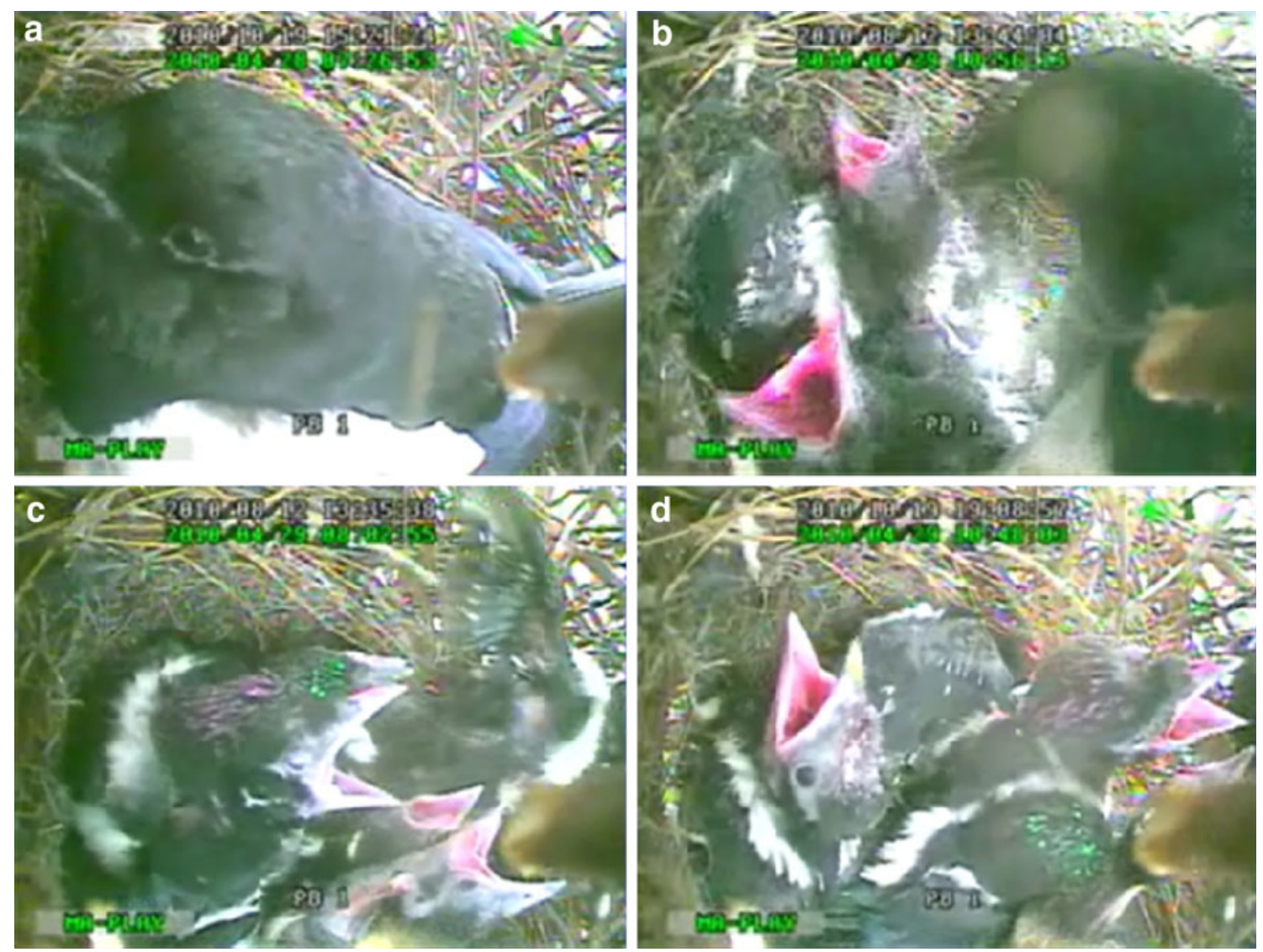

Fig. 1 Exemplary frames from each of the four video clips. The video clips show: a an incubating female, who was subsequently attacked by the perpetrator (http://www.momo-p.com/showdetaile.php?movieid=momo110422pp02a); b nestlings that are pecked on the head and body (http://www.momo-p.com/showdetail-

e.php?movieid=momo110422pp03a); c a nestling that is dragged out of the nest (http://www.momo-p.com/showdetail-e.php?movieid= momo110422bm01a); d typical begging of nestlings towards their parents (http://www.momo-p.com/showdetail-e.php?movieid=momo 110422pp01a)
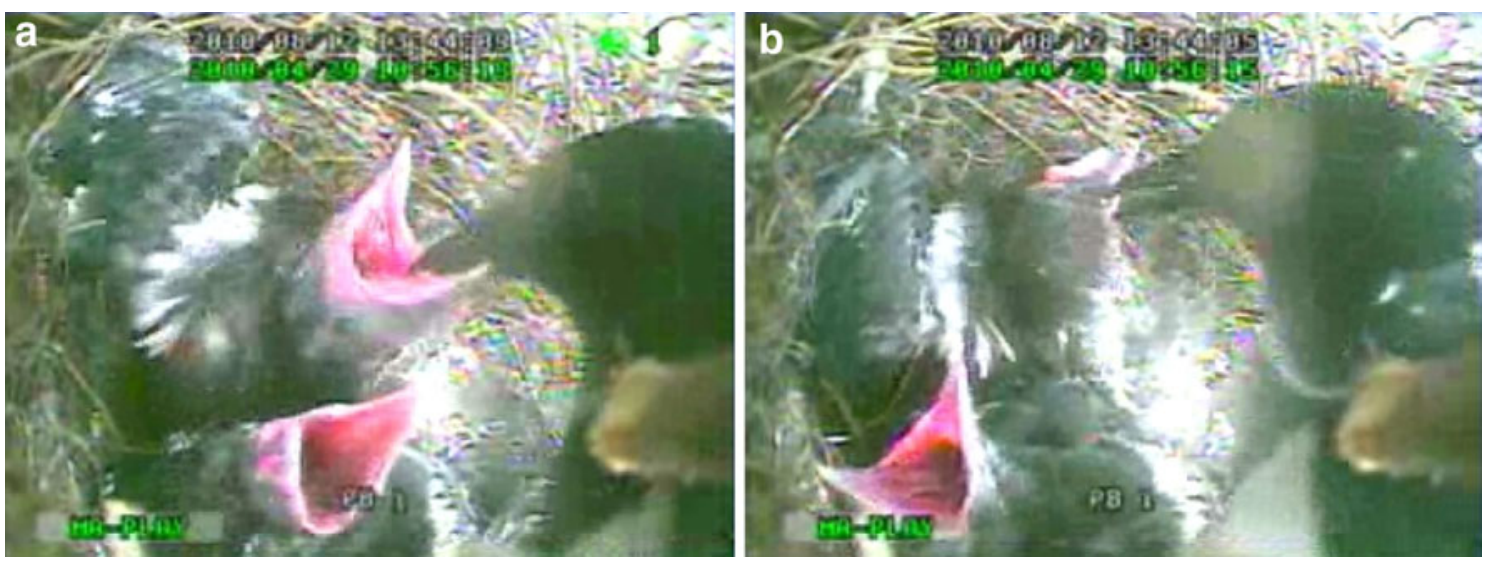

Fig. 2 Two frames from the videos showing the two specific types of behaviour of the perpetrator towards the nestlings: a the perpetrator on the right is pulling the nestling by the edge of the nestling's gape; $\mathbf{b}$ the perpetrator pecks at the forehead of the nestling

other than the nearest neighbour(s), and that more than one individual was involved in committing infanticide, we suspect that the perpetrator might have been the female (and possibly a male, see below) of the nearest neighbouring pair
(1-62), with whom the breeders of the victim's nest often had territorial conflicts. The nearest neighbouring colour-ringed male could not be excluded as the intruder because the legs of the intruder were not always visible. 
All postinfanticidal events from early summer 2010 through early February 2011 were also consistent with the idea that the nearest neighbouring female, and possibly the male as well on some but not all occasions, were the perpetrators who subsequently expanded their territory. After the infanticide, no breeding activity was observed at the nest or around the nest, and we have not observed the colour-ringed male of the victimized nest $1-60$ during regular visits to the study site after the 2010 breeding season through to February 2011. One month after the infanticide, the nearest neighbouring pair, accompanied by two fledglings, was observed in the territory of the victims' nest. For several days, they attempted to build a new nest close to the victims' nest (10 m from the victims' nest), but as it was late season they did not continue. In the subsequent months of October, November and December 2010 and January and February 2011, when territorial activities (including nest building) had already been initiated as a preparation for the next breeding season (Birkhead 1991), the suspected perpetrator (unbanded female) and her mate (banded male) were active in the vicinity of the victims' nest. Initially, they started using an old nest on a tree immediately neighboring ( $3 \mathrm{~m}$ from) the victims' nest tree (Table S2), and they were observed chasing other magpies away from this area. Later (February 2011), they begin building their own nest, which was located within the original territory of the victims (1-60). Observations from February 2011 indicated that pair 1-62 took over all of the previous territory of pair 1-60. They even expanded it through aggressive interactions with neighbours and shifted most of their activity to this new territory, decreasing their presence near the 2010 nest site, where a new pair appeared to start nest building (Table S2).

Characteristics of the breeding population at the time of infanticide

The breeding density in the 2010 season was in the lower range (37 pairs $/ \mathrm{km}^{2}$ ) in comparison to the average for the population since $1998\left(48.7 \pm 9.0\right.$ pairs $\left./ \mathrm{km}^{2}\right)$. The breeding synchrony index in the year of infanticide (21.6) was the lowest among all the seasons since 2000 (28.9 \pm 4.8 ; mean $\pm \mathrm{SD}$ ). The average density in our population, as well as the actual density in 2010, are within the upper 5th percentile of magpie densities across its geographic range in Eurasia (Fig. 2; average \pm SD: $6.9 \pm 11.2$ pairs $/ \mathrm{km}^{2}$; lower quartile: 1.1 pairs $/ \mathrm{km}^{2}$; median: 3 pairs $/ \mathrm{km}^{2}$; upper quartile: 7.8 pairs $/ \mathrm{km}^{2}$ ).

\section{Discussion}

This is the first published description of nestling infanticide in the Black-billed Magpie. Based on the physical characteristics of the perpetrator at those visits when the perpetrators characteristics were clearly visible, and the first response of the mother to the perpetrator, it is certain that it was neither the parent nor the colour-ringed male breeder of the nearest-neighbouring nest. Although it might have been any unbanded bird from the neighbourhood, the high frequency of previous interactions between the victims' parents and the nearest neighbours, and all the postinfanticide observations, indicate that the unbanded female breeder of the nearest neighbouring nest (mated with a colour-banded male) might have been the perpetrator. The nest-building activities of the nearest neighbouring pair near the victims' nest site thereafter, are consistent with the hypothesis that the neighbouring female (or both mates) might have evicted the victimized pair to gain access to the territory and the nesting site for future breeding attempts.

Adaptive explanations for non-parental infanticides involve direct exploitation (using offspring as food), sexual selection (mate replacement), and resource competition (access to food, nest site, territory, etc.). Although magpies are known to consume eggs and offspring of passerine birds, including suspected predation on their own species (Tatner 1982; Jerzak 2002), the perpetrator did not consume any part of the body of the nestlings during the attacks, and the nestlings were found dead under the nest without any signs of being eaten. Thus, we can exclude the exploitation hypothesis as the explanation for this case of infanticide.

The sexual selection hypothesis in the non-cooperatively breeding birds predicts that breeding activity would follow the infanticidal event, and that there will be a switch of partners in the territory (Møller 1988; Veiga 1990, 2004). Additionally, the competing individuals may adopt an aggressive physical takeover followed by infanticide (e.g. Freed 1986), and the remaining mate may actively participate in the infanticide (Fujioka 1986), may be totally passive (Banbura and Zielinski 1995; Ritchinson and Ritchinson 2010), or may initially be resistant (Crook and Shields 1985). According to our observations, no breeding activity by any of the victimized birds was observed in their territory after the infanticide. The victimized female was consistently-until the very last observation-equally overly aggressive towards the perpetrator, indicating that under the sexual selection hypothesis, we can only suspect an eviction of the victimized female by another female who mated with the victimized male in a distant territory. Although we cannot entirely exclude this possibility, leaving the victimized territory is not consistent with the typical pattern of sexually selected infanticide (Møller 1988, Veiga 2004), and there are scarcely any vacant territories in our densely packed population where the new pair might have settled. The suspected perpetrator (neighbouring female) remained paired to the same partner, 
which is also inconsistent with sexually selected infanticide by this female.

Two lines of evidence suggest that competition for territory and its resources might have been involved in the infanticide that we observed. First, there have often been territorial conflicts between the victim and the nearest neighbour, which may suggest that the perpetrator and the breeders of the victims' nest repeatedly competed over the food resources. Second, the pair from this neighbouring nest expanded its territory and attempted to re-nest in the territory of the victims' nest immediately after their nestlings fledged, and at the onset of the next breeding season (December 2010, January 2011, and February 2011), which may suggest that neighbouring breeders expanded their territory.

Low availability of food was probably not the direct cause of this hypothetical infanticide-mediated territory expansion. The developmental stage of the nestlings when the infanticide occurred was already beyond the steep phase of nestling growth in both the victim and the neighbouring nest, which is generally assumed to be the time of maximum food demand (Mock and Schwagmeyer 1990). The number of breeders and the distances between the nearest active nests in the year of the infanticide (2010) did not differ from other years, which may indirectly indicate similar levels of food availability (Lee et al., unpublished data). Additionally, the breeding synchrony index in the year of infanticide was lower than in other years. This may indirectly suggest that the resource competition between pairs due to the increase in synchrony of nestling demands at the population level in the year of the infanticide was no more evident than in other years. The provisioning rate frequency by the parents and the nestlings' body conditions before the infanticidal events were similar to those of other nests (Lee et al. 2010b), thus excluding the possibility of a severe local decrease in food availability in the area near the victim nest. Therefore, it is likely that there was no unusual local increase in the need for food resources that might have been associated with the infanticide-mediated access to neighbouring territory. We thus suggest that if the neighbouring female (or the pair) was the perpetrator, she (they) gained the long-term territory expansion and new potential nesting sites for the future breeding attempts. They also gained access to a small artificial water pool (present in the victims' territory) surrounded by vegetation, which may hypothetically provide better resources than their previous nest site. It is likely that such a long-term infanticidal territory takeover is, similar to sexually selected infanticides (Møller 1988), more likely at very high densities, when competition for territories is extreme. Consistent with this view, our study population is one of the most dense magpie populations studied (Fig. 3), while there are no published records of

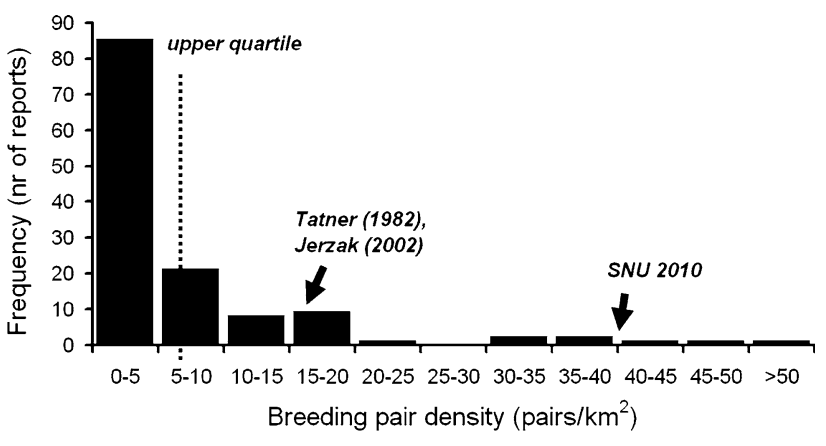

Fig. 3 Distribution of breeding pair densities (pairs $/ \mathrm{km}^{2}$ ) of the Black-billed Magpie across Eurasia $(n=131$ reports from Jerzak 2002). Our study population (SNU), as well as the two populations where the destruction of magpie broods by other magpies was observed (Jerzak 2002; Tatner 1982), are marked by arrows on the density scale

infanticide from similar video recordings of nests in a relatively low-density $\left(0.82-4.15 \mathrm{pairs} / \mathrm{km}^{2}\right.$; Martinez et al. 1996) magpie population in Hoya de Guadix, Spain (Moreno-Rueda et al. 2007). We think that some of the published cases of suspected predation by magpies on magpie broods (Jerzak 2002; Tatner 1982) might have indicated infanticide events, because they also come from populations with relatively high densities (Fig. 3).

In summary, this is the first report of non-parental infanticide in the Black-billed Magpie Pica pica. The perpetrator(s) might have been the female, and possibly also the male, breeder of the neighbouring nest. Postinfanticide expansion of their breeding territory is the hypothetical ultimate explanation of the observed infanticide. In dense populations, with relatively small breeding territories, such an expansion may have high adaptive value.

Acknowledgments We are grateful to magpie team members for sharing all the field work. This study was supported by the "Longterm Ecological Monitoring on Animal Populations" program of the Ministry of Environment, and partly by National Research Foundation grant nos. 2011-0003944; 2010-0029613; 2010-K001149; 2010-0025546; 2007-313-C00747, as well as the Brain Korean 21 Project 2010. The field method employed in this study complies with the current laws of South Korea.

Open Access This article is distributed under the terms of the Creative Commons Attribution Noncommercial License which permits any noncommercial use, distribution, and reproduction in any medium, provided the original author(s) and source are credited.

\section{References}

Banbura J, Zielinski P (1995) A clear case of sexually selected infanticide in the swallow Hirundo rustica. J Ornithol 136:299-301 
Birkhead TR (1991) The magpies: the ecology and behaviour of Black-billed and Yellow-billed Magpie. T \& A.D. Poyser, London

Crook JR, Shields WM (1985) Sexually selected infanticide by adult male barn swallows. Anim Behav 33:754-761

Emlen S, Demong NJ, Emlen DJ (1989) Experimental induction of infanticide in female wattled jacanas. Auk 106:1-7

Freed LA (1986) Territory takeover and sexually selected infanticide in tropical house wrens. Behav Ecol Sociobiol 19:197-206

Fujioka M (1986) Infanticide by a male parent and by a new female mate in colonial egrets. Auk 103:619-621

Hansson B, Bensch S, Hasselquist D (1997) Infanticide in great reed warblers: secondary females destroy eggs of primary females. Anim Behav 54:297-304

Hausfater G, Hrdy SB (1984) Infanticide: comparative and evolutionary perspectives. Aldine, New York

Hrdy SB (1979) Infanticide among animals: a review, classification, and examination of the implications for the reproductive strategies of females. Ethol Sociobiol 1:13-40

Inoue Y, Yoda K, Fujii H, Kuroki H, Niizuma Y (2010) Nest intrusion and infanticidal attack on nestlings in great cormorants Phalacrocorax carbo: why do adults attack conspecific chicks? J Ethol 28:221-230

Jerzak L (2001) Synurbization of the Magpie Pica pica in the Palearctic. In: Marzluff JM, Bowman R, Donnelly R (eds) Avian ecology and conservation in urbanizing world. Kluwer Academic Publishers, Boston, pp 405-427

Jerzak L (2002) Synurbization of the black-billed magpie (Pica pica) in Eurasia (in Polish: Synurbizacja sroki Pica pica w Eurazji). Wydawnictwo Naukowo-techniczne, Uniwersytet Zielnogórski, Zielona Góra

Kaplan G (2004) Australian Magpie: biology and behaviour of an unusual songbird. CSIRO, Melbourne

Kermott LH, Johnson LS, Merkle MS (1991) Experimental evidence for the function of mate replacement and infanticide by males in a north-temperate population of house wrens. Condor 93:630-636

Lee S-I, Hwang Y, Lee J, Choe JC (2010a) Unusual pattern of sexspecific mortality in relation to initial brood sex composition in the black-billed magpie Pica pica. J Avian Biol 41:139-146

Lee S-I, Choi J, Jablonski PG, Choe JC (2010b) Parental provisioning in response to natural variation of brood size in the Black-billed Magpie (Pica pica): video analysis of the behaviors in the nests. Polish J Ecol 59:553-562

Martinez JG, Soler M, Soler JJ (1996) The effect of magpie breeding density and synchrony on brood parasitism by great spotted cuckoos. Condor 98:272-278
Mock DW (1995) The evolution of parental optimism. TREE 10:130-133

Mock DW, Schwagmeyer PL (1990) The peak load reduction hypothesis for avian hatching asynchrony. Evol Ecol 4:249-260

Møller AP (1988) Infanticidal and anti-infanticidal strategies in the swallow Hirundo rustica. Behav Ecol Sociobiol 22:365-371

Møller AP (2004) Rapid temporal change in frequency of infanticide in a passerine bird associated with change in population density and body condition. Behav Ecol 15:462-468

Moreno-Rueda G, Soler M, Soler JJ, Martinez JG, Perez-Contreras T (2007) Rules of food allocation between nestlings of the blackbilled magpie Pica pica, a species showing brood reduction. Ardeola 54:15-25

Mumme RL, Koenig WD, Pitelka FA (1983) Mate guarding in the acorn woodpecker: within-group reproductive competition in a cooperative breeder. Anim Behav 31:1094-1106

Parsons J (1971) Cannibalism in herring gulls. Br Birds 64:528-537

Prokop P, Trnka R, Trnka A (2009) First videotaped infanticide in the common pochard Aythya ferina. Biologia 64:1016-1017

Ritchinson G, Ritchinson BT (2010) Infanticide by an Eastern Phoebe. Wilson J Ornithol 122:620-622

Shimada T, Kuwabara K, Saori Y, Shichi T (2002) A case of infanticide in the spot-billed duck in circumstances of high breeding density. J Ethol 20:87-88

Tatner P (1982) Factors influencing the distribution of magpies Pica pica in an urban environment. Bird Study 29:227-234

Trail PW, Strahl SD, Brown JL (1981) Infanticide in relation to individual and flock histories in a communally breeding bird, the Mexican jay (Aphelocoma ultramarina). Am Nat 118:72-82

Veiga JP (1990) Infanticide by male and female house sparrows. Anim Behav 9:496-502

Veiga JP (2000) Infanticide by male birds. In: van Schaik CP, Janson $\mathrm{CH}$ (eds) Infanticide by males and its implications. Cambridge University Press, Cambridge

Veiga JP (2003) Infanticide by male house sparrows: gaining time or manipulating females? Proc R Soc Lond B 270(Supp 1):S87S89

Veiga JP (2004) Replacement female house sparrows regularly commit infanticide: gaining time or signaling status? Behav Ecol 15:219-222

Verbeek NAM (1972) Comparison of displays of the Yellow-billed Magpie (Pica nuttalli) and other corvids. J Ornithol 113:297-314

Westneat DF (1992) Nesting synchrony by female Red-winged Blackbirds: effects on predation and breeding success. Ecology 73:2284-2294 